\title{
ONLINE MARKETING DALAM KOMUNIKASI PEMASARAN PULSA ELEKTRIK DI KIOS CELL KOTA BENGKULU
}

Oleh:

\author{
EFRI AGUS, VETHY OCTAVIANI, YUSUARSONO \\ Program Studi Ilmu Komunikasi Fakultas Ilmu-Ilmu Sosial \\ Universitas Dehasen Bengkulu
}

\begin{abstract}
According to research it is obtained: attention, interesting display and pictures of electric balance which can attract customer and make them interest to try and top-up balance because the transaction is fast, easy on delivery and cheap also various model which displayed. Society can also a new agent, kios cell open for 24 hours so customer can always be served. Interest because of online advertisement by showing the price is cheaper than other sellers, but the problem comes from internet connection so it delays in sending the electric balance. Desire is still in customer who being aware in top-up electric balance with online media, cheap and fast in every transaction makes customers satisfy. The loss when sending the balance get delayed so that account will use personal balance which caused the customer loss. Action of kios cell owner can give a guidance through brochure and give direct guidance to customer about how to do a transaction in purchasing electric balance through facebook or token.
\end{abstract}

\section{Keywords: online media marketing, market communication}

\section{PENDAHULUAN}

Media online merupakan media terbaru dalam dunia kominikasi dengan hadirnya media online ini masyarakat bisa berkomunikasi dari jarak yang jauh, dalam dunia marketing media online merupakan media yang baru bagi para pelaku bisnis sehingga banyak yang tertarik untuk mencoba berbisnis dengan memenfaatkan media online salah satunya berjualan pulsa banyak agen atau blok yang menawarkan pulsa dengan harga yang relatip lebih murah, sehingga media online merupakan salah satu pesaing yang dikahwatirkan para penjual pulsa secara langsung atau konter, Media online yang mejual pulsa seperti paytren, kudo, bukalapak.com belibeli.com.
Namun banyak mayarakat belum begitu percaya dengan media online ini, karena masyarakat masih takut yang disebabkan maraknya penipuan yang dilakukan oknum yang tidak bertanggung jawab.

Konter merupakan agen atau para pelaku bisnis yang menjual kebutuhan alat komunikasi HP, dengan meningkatnya kebutuhan masyarakat akan pulsa maka banyak sekali konter yang tersebar di negeri ini dari kota sampai kepelosok desa, dengan berbagai cara yang dilakukan untuk memasarkan produk yang mereka jual, untuk menarik sempatik para pembeli untuk berbelanja dikonter meraka masing-masing, mulai dari pembutan pamplet, browsure, serta ada yang memberikan hadia-hadia yang menarik 
bagi setiap pelanggan bagi yang telah berlangganan lama. Serta ada yang melakukan pemasran dengan cara yang unik dengan menghadirkan badut, supaya menarik pembeli untuk berbelanja.

Komunikasi pemasaran merupakan usaha untuk menyampaikan pesan kepada publik terutama khalayak sasaran mengenai keberadaan produk dipasar yang menawarkan berbagai manfaat dan keuntungan. Karena itu komunikasi pemasaran memegang peranan yang sangat penting bagi pemasaran, tanpa komunikasi pemasaran konsumen tidak akan mengetahui keberadaan produk dipasar, tetapi banyak cara untuk meningkatkan pemasaran dalam meningkatkan pendapatan suatu perusahaan, salah satu kegiatan yang dilakukan yaitu dengan membuat rencangan, baik rancangan dalam pemasaran maupun strategi komunikasi. Strategi pemasaran yang dikembangkan berupa bauran pemasaran (marketingmix) yang meliputi empat hal pokok yaitu produk (product), harga (price ), promosi (promotion), distribusi (place). Bisa disingkat 4P, Setelah proses pemasaran dikembangkan yang meliputi 4P dalam penerapannya bisa melebar pada spectrum yang lebih luas. Langkah pertama yaitu menentukan produk yang akan ditawarkan dengan segala pertimbangan misalnya kualitas, ukuran, bentuk, warna, kemasan dan lainnya. Langkah kedua yaitu menentukan berapa harga produk itu akan ditawarkan kepada konsumen.

Penentuan harga ini juga harus melalui banyak pertimbangan misalnya daya beli konsumen, marjin yang diinginkan dan lainnya. Langkah ketiga yaitu menentukan bauran promosi yang akan ditempuh untuk mengkomunikasikan produk kepada konsumen. Philip Kotler mengidentifikasikan bauran promosi (promotionmix) sebagai berikut : promosi penjualan, iklan, hubungan masyarakat dan publisitas, penjualan pribadi dan penjualan langsung. Selanjutnya langkah keempat yaitu menentukan saluran distribusi yang akan dipakai agar produk yang ditawarkan bisa terjangkau oleh sasaran bangsa pasar.

Selain itu rencana pemasaran adalah salah satu tugas penting bagi seorang manajer pemasaran dalam perusahaan dan merupakan salah satu hal yang tidak mudah ditangani secara spesifik maka para manager perusahaan dituntut untuk selalu mengembangkan cara-cara baru yang kreatif dan inovatif agar produk yang dikomunikasikan tersebut dapat bersaing dengan produkproduk lain yang sejenis dan pada akhirnya dapat diminati oleh khalayak sasarannya. Walaupun dalamprakteknya seringkali ditemukan kegagalan suatu produk dipasaran dikarenakan salahnya rencana komunikasi pemasaran yang diterapkan tidak sesuai dengan kondisiyang selalu berubah-ubah, dengan kata lain para manajer pemasaran atau pengelola perusahaan yang tidak memahami kondisi pasar.

Pemasaran suatu produk sebaiknya terencana sehingga apa yang dipasarkan dapat terjual sesuai dengan target atau rencana, apa lagi dalam penjualan pulsa, karena pulsa merupakan kebutuhan masyarakat yang luas bagimana cara pelaku bisnis bisa menjual produk mereka tujuan awal sehingga dapat mencapai tujuan awal, namun pejual pulsa harus la jeli dalam memilih lokasi tempat berjualan, serta tahu sepesipik pulsa itu sendiri karena pulsa itu terdiri dari dua jenis ada pulsa yang mempunyai wujud atau fisik dan ada pulsa yang tidak memiliki wujud atau yang disering disebut elektrik, pada saat ini banyak sekali konter yang 
menjual pulsa, apa lagi dengan sistem elektrik dengan satu cip saja bisa menjual pulsa semua oprator. Dengan kemajuan ternologi saat ini maka kebutuhan masyarakat akan pulsa pun semakin meningkat, begitupula dengan konter dikota kota seperti Duta Ponsel, M98, Panorama cell, dan konter Kios Cell yang ikut bersaing dalam menjual pulsa elektrik, dengan sistem pemasaran dengan harga yang sudah tertera di berbagai pamplet atau brosur yang ada di teras konter, kios cell merupakan sebuah usaha milik keluarga yang berdiri pada 07 Januari 2014, beralamat di Jln. Mangga Raya Simpang 4 Taman Remaja Bengkulu. Kios cell sangat mengutamakan pelayanan yang memuaskan pelanggan, dengan melengkapi kebutuhan pelanggan di bidang baik kartu kuota, elektrik maupun pulsa, sehingga pelayanan yang memuaskan membuat pelanggan, nyaman berbelanja di kios cell.

Dari laporan yang ada di kios cell terlihat, bahwa kios cell belum dapat mencapai target yang diinginkan dalam hal ini ditegaskan oleh marketing kios cell langsung yaitu saudara Edo mengatakan dalam memasarkan produk melalui online kita masih terhalang oleh beberapa masalah salah satunya kurangnya peminat pelanggan disebabkan masih adanya keraguan oleh pelanggan, pembeli merasa takut akan kebenaran atau keaslian situs penawaran.

Promosi yang dilakukan konter kios cell dikategorikan belum mumpuni, untuk menghadapi persaingan penjualan di kota Bengkulu, Sehingga membuat kios cell sepi pengunjung dikarenakan harga penjualan yang memiliki selisih harga dengan konter saingan yang ada disekitar kios cell. Seperti pulsa lima ribu seharga enam ribu rupiah sedangkan di kios cell harga pulsa lima ribu dijual seharga tujuh ribu rupiah, dengan perselisihan harga ini membuat masyarakat kurang berminat untuk membeli produk yang dipasarkan oleh kios cell, dengan adanya persaingan yang sesama konter membuat kios cell harus bekerja ekstra untuk merebut perhartian masyarakat, meskipun itu sudah dilakukan dengan menawarkan produknya dengan membuat berbagai iklan, seperti pembuatan spanduk yang mencolok, menyebarkan pamplet disekitar kios cell, tetapi pengunjung masih kurang berminat untuk berbelanja dikios cell.

\section{METODE PENELITIAN}

Jenis penelitian yang digunakan oleh penelitian ini adalah penelitian yang disajikan secara deskritif kualitatif. Dimana nantinya peneliti akan melakukan penelitian secara langsung di konter kios cell dimana penelitian ini peneliti akan mengamati terdahalu kegiatan atau pemasaran yang dilakaukan kios cell untuk menarik peminat pembeli, setelah itu melakukan wawancara guna menggali informasi yang lebih dalam lagi. Sedangkan menurut ahli Bodgan dan Taylor (1991:21-22) dalam buku Basrowi dan Suwandi (2008:1) menyatakan bahwa penelitian kualitatif adalah salah satu prosedur penelitian yang menghasilkan data deskriftif yang berupa ucapan dan tulisan dan prilaku orang-orang yang diamati.

Menurut Sugiyono (2012:7-8) penelitian kulitatif adalah penelitian tentang risetyang bersifat deskriftif dan cenderung menggunakan analisi. Proses dan makna (perspektif subyek) lebih ditonjolkan dalam penelitian kualitatif. Dengan landasan teori ini akan dimanfaatkan penulis sebagai panduan agar fokus penelitian sesuai denganfakta yang ada dilapangan. Selain itu landasan teori ini juga bermanfaat untuk memberikan gambaran umum tentang 
latar penelitin dan sebagai bahan pembahas hasil penelitian. Teknik pengumpulan data menggunakan metode observasi, wawancara, dan dokumentasi berupa tulisan, photo, arsip atau keterangan tertulis yang dapat membantu peneliti mempertanggung jawabkan apa yang sedang diamati.

\section{HASIL PENELITIAN DAN PEMBAHASAN}

Penelitian ini dilakukan melalui tahapan-tahapan diantaranya tahapan proses wawancara, observasi, dan dukumentasi. Metode yang digunakan dalam penulisan ini adalah metode analisis data kualitatif dilakukan secara terus menerus interatif disetiap tahap penelitian sehingga selesai. Data yang disajikan penelitian dengan mengelompokan data secara sistematis dalam bentuk sekripsi agar mudah dipahami dalam berbagai interaksi antara bagian-bagiannya dalam intraksi yang utuh.

Dalam melakukan penelitian ini penulis melakukan wawancara pada penguna dan pemakai pulsa elekterik khususnya masyarakat Kota Bengkulu. Penelitian ini menggunakan teori model AIDA, yang dikemukan oleh Kotler dan Keller (2009:179).

Dari kerangka pemikiran diatas maka penulis akan meneliti berdasarkan model AIDA : Produk pulsa elektrik banyak sekali dipakai dan dinikmatai oleh konsumen dikarenakan harganya terjangkau, mudah diakses dan trasaksinya cepat baik itu pada siang hari maupun malam hari.Akibatnya konsumen dapat dengan mudah mengunakan aksesnya dalam pemakaianya, walaupun terkadang ada saja hambatan kecil yang sering terjadi akibat error jaringan internet yang mana pemakainya banyak dipakai atau digunakan oleh masyarakat. Sehinga hal-hal tersebut menjadi kendalah bagi pemakaianya sehingga perhatiannya pada pemilik kios cell harus dapat memperhatikan keluhan pelangan dan penguna pulsa elektrik.

Selain proses yang di amati penulis selama penelitian Pelayanan yang harus dilakukan oleh pemilik kios cell kepada konsumen hendaknya memberikan penjelasan-penjelasan atas kegungulan produk tersebut. Agar para kunsumen dapat mengerti dan manfaat yang digunakan, berikan penjelasan yang mudah dipahami sehingga menarik konsumen untuk memakai atau membeli pulsa elekrik di kios cell tertentu. Pemilik kios cell dalam hal ini haruslah ramah, sopan dan murah senyum agar dapat mendatangkan pelanggan atau konsumen datang kembali. Konsumen sebenarnya harga tidak menjadi sebuah patokan harga tetapi pelayanan yang menjadi modal mereka merasakan puas atau tidaknya puas yang dilakukan oleh petugas yang melayanai pada saat itu. Sehingga ketertaikan untuk kembali lagi membeli di kios cell tersebut akan lebih gampang. Biasanya konsumen ini akan bercerita kepada temen-temanya bahwa pelayanannya di kios cell tersebut sangat memuaskan.

Setelah melakukan pengamatan penulis, Konsumen sebelum memakai pulsa elektrik harus banyak mencari tahu terlebih dahulu tentang suatu produk tersebut yang dipasarkan dikios cell. Agar produk yang kita beli bisa kita gunakan dalam pemakaianya menjadi lebih puas, sehinga menarik konsumen yang lainya untuk dapat membeli dan menjadikanpertimbangan tersendiri saat akan melakukan transaksi pembelian pulsa elektrik. Dan akan gampang sekali memilih produk yang dipasarkan sehiga konsumen menjadikan sebuah kebutuhan terutama pembelian pulsa elektrik di kios cell. Karena harganya terjangkau dan mendapatkan potongan harga dalam 
pembelian pulsa elektrik lebih dari satu juta.

Selain itu penulis mengamati dari pihak kioscell harus cepat mengambil keputusan dalam memberikan penjelasan melalui berosur tentang pulsa elektrik kepada konsumen agar pelangan bisa datang kembali untuk pembelian pulsa elektrik yang disediakan di kios Cell. Konsumen tidak akan piker panjang ketika pihak kios cell memberikan penawaran dan penjelasan mengenai pulsa elektrik yang dapat digunakan. Berikanlah keunggulan-keungulan yang ada pada kios cell diwaktu konsumen membutuhkan teransaksi baik pada siang hari maupun malam hari. Ada kios cell yang buka 24 jam mereka siap dihubungi kapan saja asalkan adanya kerjasama antra konsumen dan pihak kios cell.

\section{PENUTUP}

\section{Kesimpulan}

Berdasarkan hasil penelitian dan pembahasan mengenai Bagaimana Online Marketing dalam komunikasi pemasaran pulsa elektrik di Kios Cell kota Bengkulu. Dimana dalam penelitian ini mengunakan teori model AIDA, yang dikemukan oleh Kotler dan Keller (2009:179) menjelaskan Teori AIDA (Attention, Interest, Desire, and Action) merupakan suatu pesan yang harus mendapatkan perhatian, menjadi ketertarikan, menjadi minat, dan mengambil tindakan. Teori ini menyampaikan akan kualitas dari pesan yang baik. Definisi di atas dapat diimplikasikan bahwa AIDA (Attention, Interest, Desire, and Action) merupakan alat penyampaian suatu pesan yang ideal kepada konsumen di mana melalui suatu tahapan yang terdiri dari perhatian (Attention/Awareness), ketertarikan (Interest),minat (Desire), dan mengambil tindakan (Action). Hal ini di mana seorang pemasar harus menyadari bahwa pesan yang disajikan tentang AIDA (Attention, Interest, Desire, and Action)

1. Dalam tampilanya menunjukan pulsa elektrik gambar dan tampilanya menarik sehinga konsumen tertarik untuk mencoba dan membeli Pulsa Elektrik. Dengan demikian transaksinya lebih cepat, mudah terkirim, dan harganya terjangkau semua lapisan pengunanya. Model produk yang ditampilkan beragam banyak macamnya. Dan dapat pula menjadi agen baru, kios cell selalu buka 24 jam sehinga konsumen dapat terlayani

2. Pembelian Pulsa Elektrik melalui media online mudah dilakukan dengan harga pulsa elektrik lebih murah dibandingkan dengan harga yang lainnya, sedangkan kerugianya jaringan Internetnya sedang mengalami gangguan sehingga terlambat pulsa elektrik masuk ketangan konsumen.

3. Masih ada konsumen yang berhatihati dalam pembelian pulsa elektrik yang sipatnya mencoba untuk pemakaianya melalui media online, harganya terjangkau, murah dan cepat masuk dalam transaksi pembelian pulsa sehinga pelayanan yang diberikan cukup memuaskan. Kerugianya jika pulsa yang dikirimkan pada komsumen lama masuknya tidak dikirimkan oleh akun tersebut pulsa pribadi kita.

4. Pemilik kios cell memberikan petunjuk melaluibrosur dan memberikan penjelasan secara langsung dalam transaksi kepada konsumen untuk belajar cara atau langka-langka pembelian Pulsa Elektrik melalui media Online Facebook atau Sms ke Nomor Handphone Agen terdaftar. 


\section{Saran}

Berdasarkan hasil penelitian tersebut, maka ada beberapa saran yang dapat diberikan antara lain:

1. Tingkatkan Pelayanan Kios Cell dalam Bertransaksi Pulsa, Kecepatan Transaksi Mempengaruhi Konsumen Berlangganan. Operator Kios Cell harus memberikan Kecepatan Pelayanan dalam Keadaan Jaringan Offline.

2. Marketing Kios Cell selalu cari Konsep untuk memasarkan Produkproduk Pulsa Elektrik Kios Cell di Media Online,jangan Cuma Facebook wadah Mempromosikan Iklan,di Media Online Ada Beberapa Aplikasi yang bisa kita Promosikan Iklan seperti Instagram,Line, Twiter dan Lainlain.

3. Berjalannya Waktu Kios Cell boleh memberikan Promo-promo kepada konsumen untuk menarik konsumen dalam melakukan deposit pulsa.

\section{DAFTAR PUSTAKA}

Arnott, David C. dan Susan Bridgewater,2002.'Internet,Intera ction and Implications for Marketing," Marketing Intelligence dan Planning,20 (2):86-95.

Bennet, R,1997.'Export Marketing and the Internet: Experience of Web Site Use and Perceptions of Export Barriers among UK,"Businesses Industrial Marketing Review,14 (5):324344.

Chaffey,D.,Mayer R.,Johnston,K.,dan Elliss-Chadwick,F.,2000. Internet Marketing: Strategy, Implementation, and Practive. England: Prentice Hall.

Chandra, Gregorius,2001. Pemasaran Global.ed 1.Yogyakarta: Penerbit Andi.

Hamill,Jim,1997.'The Internet and International Marketing, " International Marketing Review, 14(5):300-323.

Hoffman,D.L.dan Novak,T.P.,1996.”A New Marketing Paradigm for Electronic Cammerce,"The Information Society:Special Issues On Electronic Ecommerce,13 (1):43-54. 